\title{
Access to Higher Education in Canada ${ }^{\dagger}$
}

\author{
NEIL GUPPY*
}

\begin{abstract}
This paper examines changes in access to higher education in Canada for individuals born in the first half of this century. The data show variations in attendance at, or graduation from, university or non-university postsecondary educational programmes by gender, language group, and socioeconomic background. The statistical analysis uses information from a large, nationally representative sample of Canadians. Results show a process of democratization at the postsecondary nonuniversity level, but only a modest reduction in disparities at the university level.
\end{abstract}

\section{RÉSUMÉ}

Cet article est un examen des changements encourues eu égard à l'accessibilité à l'enseignement supérieur au Canada pour les personnes nées dans la premièremoitié sexe, langue maternelle et milieu socio-économique pour les inscrits et les diplômés de niveau universitaire ou de niveau postsecondaire autre qu'universitaire. més de niveau universitaire ou de niveau postsecondaire autre qu'universitaire. $L$ 'analyse statistique utilise les données d'un échantillon grand et représentatif de la population du Canada. Les résultats révèlent une plus grande démocratisation ou niveau postsecondaire autre qu'universitaire tandis que l'affaissement des disparités est plutôt négligeable à l'université.

At the turn of this century Canadian higher education was predominantly, although not exclusively, the preserve of upper class, Anglo-Canadian males. Clearly this is no longer the case. While it might be tempting to believe that the attainment of higher education is now independent of an individual's gender, ethnicity or socioeconomic background, contemporary evidence shows such a view would

†This research was supported by U.B.C. research grant \#26-9258. The data used herein were collected, with SSHRCC funding, by M. Boyd, J. Goyder, F. Jones, H. McRoberts, P. Pineo and J. Porter. I am grateful to the Canadian Mobility Study project group for making their data publicly available. My thanks also to Jane Gaskell, David Pedlar, and Robert Pike for providing instructive comments on a previous draft of this paper. None of these individuals are responsible for the interpretations presented.

* Department of Anthropology and Sociology, University of British Columbia 
be unfounded (see e.g., Anisef, Okihiro and James, 1982; Lennards, 1983:451. 53). Although accessibility is presumably more open now, it is unclear exactly how much democratization in higher education has occurred over the course of this century.

Given the massive quantities of public monies provided for education, the great expectations held by many people for the fruits of educational expansion, and the innumerable discussions educators, sociologists and others devoted to equality of opportunity debates, it is astonishing to find that little empirical evidence is available to document changes in the degree of access to postsecondary schooling. Testimony to this void is found in Robert Pike's lament, in his 1970 report for the Association of Universities and Colleges of Canada, that the "lack of contemporary research on the changes which may have occurred in class differentials in educational opportunity . . . is quite deplorable" (Pike, 1970: 55).

Over the last decade some research has been undertaken to fill this void. First, Harvey (1977) compared national samples of postsecondary students from the periods 1968-69 and 1974-75 in an effort to detect trends in enrolment patterns by gender and socioeconomic background. His general findings were that women's enrollment had increased over the six year period, as had the proportion of students from lower socioeconomic backgrounds, although the latter increase tended to be less pronounced. Second, Anisef, Okihiro and James (1982) used special computer runs from the 1971 and 1976 Canadian censuses to monitor accessibility to postsecondary education in Ontario. For women and for most ethnic groups, they documented significant gains in access at both postsecondary university and non-university levels. However, contrary to Harvey's results, they found no evidence of a narrowing in the educational disparities between social classes. $^{1}$

While both studies represent commendable beginnings to a research programme focused on past, present and future changes in accessibility to higher education, these first studies constitute only limited approaches to the study of change since they focus on periods of less than a single decade. But, despite the limited empirical evidence on changes in accessibility, several social commentators have speculated on trends in educational democratization. Sutherland (1975: xvii), for example, claims that "mass education has ensured that the old divisions of power and resources were maintained and extended into nineteenth and twentieth century urban and industrial society." In a similar vein, Lennards (1983: 452) suggests that "educational expansion has not succeeded in reducing existing social class differentials in university attendance."

Although no one familiar with the issue claims that class background and postsecondary access are unrelated, some commentators have indicated modest decreases in the disparity between classes. Pike (1980:132) suggests that, while small changes may have occurred over time in the class composition of university students, much more dramatic democratization characterizes community colleges. Harvey's (1977) evidence provides mixed support for this contention (see also Goyder, 1980: 33). 
With respect to historical differences in attainment for women and ethnic minorities, many writers suggest that more equitable participation has recently occurred (e.g., Gaskell, 1981: 173-77; Pike, 1980:133; Lennards, 1983: 451). The general consensus is that democratization of higher education by gender and ethnicity began primarily in the 1960's and continued through the 1970's.

Based on the preliminary research noted above, and attending to the comments of those writing about access to higher education, three contrasting hypotheses can be distilled from the existing literature. After describing each hypothesis immediately below, I proceed to examine empirical evidence designed to test the relative merits of each.

One hypothesis, the constant gap hypothesis, predicts that over time, in higher education, the relative proportion of individuals from different class, gender or ethnic backgrounds has remained fixed. While we know that the number of postsecondary students has increased over time, under this hypothesis increases should have come equally from all groups. This hypothesis would be supported by those who believe the educational system has done nothing to ameliorate the attainment chances of individuals from disadvantaged groups.

A second hypothesis, the steadily declining gap hypothesis, predicts that over time there has been a constant narrowing of the gap in participation rates between groups. The increasing numbers of postsecondary students are thought to come disproportionately, relative to some previous point, from one particular group. For example, to achieve a narrowing of the gap between men and women at the postsecondary level, there must have been a growing proportion of women relative to men in each successive time period, although there may still be more men than women at postsecondary institutions. This hypothesis is supported by those who believe that, with the relative progress of this century, there has been a concommitant increase in the equality of educational opportunity.

A third hypothesis, the accelerating decline hypothesis, also postulates a narrowing of the gap between groups, but considers the rate of this convergence to be accelerating in recent times. This means that, over the years, the proportion of students in higher education from one group increases, relative to a second group, at a rate which grows as time passes. For example, the percentage of students from lower class backgrounds, as compared to upper class backgrounds, grows at an exponential rate. Support for this hypothesis comes from those who believe that the rapid post-WW II expansion of the postsecondary system led to a greater democratization of higher education.

For gender and ethnicity, the general consensus is that the accelerating decline hypothesis holds for all levels of postsecondary education (see e.g., Anisef, Okihiro and James, 1982: 110; Lennards, 1983). For socioeconomic status, the most popular prediction is that the constant gap hypothesis holds at the university level (references above), but the accelerating decline hypothesis fits more closely at the community college level (references above).

Despite a wealth of speculative comment, there is little in the way of published research illustrating which pattern, hypothesized above, best conforms to the 
Table 1: University Degree Attainment by Birth Cohort and Father's Education (Males only)'

Birth Cohort

\begin{tabular}{l|r|r|c|}
$\begin{array}{l}\text { Father's } \\
\text { Education }\end{array}$ & $1902-21$ & $1922-41$ & $1942-46$ \\
\cline { 2 - 4 } $\begin{array}{l}\text { University } \\
\text { Degree }\end{array}$ & $49.1 \%$ & $56.9 \%$ & $60.9 \%$ \\
\cline { 2 - 4 } $\begin{array}{l}\text { Non-Univ. } \\
\text { Disparity Ratio }\end{array}$ & $5.99: 1$ & $4.78: 1$ & $2.68: 1$ \\
\cline { 2 - 4 } & $8.2 \%$ & $11.9 \%$ & $22.7 \%$ \\
\cline { 2 - 4 } Log Distance & 1.78 & 1.56 & .99 \\
& &
\end{tabular}

'Source: Michel D. Lagace, "Educational Attainment in Canada: Some Regional and Social Aspects" Dominion Bureau of Statistics, Special Labour Force Studies, Number 7, October, 1968. (Calculations are my own.)

historical development of Canadian education. Using a large national sample, I endeavour to trace alterations in rates of higher educational participation between the 1920's and 1970's by gender, socioeconomic origin, and language group. The evidence discussed below indicates that university accessibility has become more attainable for women and French-Canadians, although little democratization by socioeconomic origin has occurred. Furthermore, the evidence highlights an increasing duality in postsecondary education, where colleges and universities serve different social groups.

\section{Methodological Issues}

Before proceeding to outline the data and methods used here to evaluate changes in equality of access, I should briefly comment on different issues involved in assessing educational inequality (the following draws upon Mare, 1980; and Simkus and Andorka, 1982). During this century the average level of education of the Canadian population has increased. Concurrent with this increasing average, the difference between the most and least educated groups has narrowed. In statistical terms, while the mean or average has risen, the variance or standard deviation of the schooling distribution has been reduced (see results in Harp, 1980: 232; Hunter, 1981: 75). ${ }^{2}$ Although the dispersion of the educational distribution has narrowed over time, this says nothing about whether the processes that allocate people to different levels of schooling have changed. That is, ascriptive procedures, as opposed to achievement processes, may still operate. ${ }^{3}$ In addition, the distribution may have narrowed because of changes at various levels of schooling such that processes occurring at the secondary and postsecondary level need not be identical.

Table 1, containing data from Lagace (1968), provides a concrete illustration of some of the points mentioned above. The table cross-classifies individual uni- 
versity attainment by birth cohort and father's education, for males responding to the January 1966 Canadian Labour Force Survey $(N=35,000)$. The figure in each cell of the table represents the percentage of respondents who reported university degrees. For instance, the figure of 49.1 percent in the top left-hand cell means that for those respondents in the 1902-21 birth cohort whose fathers had a university education, almost half obtained their own university degree. ${ }^{4}$

While social scientists have become skilled in interpreting simple contingency tables, problems of interpretation arise in analyzing issues of trend using crossclassified data, such as in Table 1. Although the percentages for individual cells may hold some intrinsic interest, far more about patterns of change can be learned by comparing trends in cell ratios. Using father's education as a crude measure of social origin, relative class chances can be examined by computing disparity ratios (the ratio of the percentage from each social background obtaining university degrees). ${ }^{5}$ These ratios, displayed in the third row of the table, show that early in this century the chance of obtaining a university degree was six times more likely for men from privileged backgrounds (i.e., those whose fathers had university degrees), relative to men whose fathers were less privileged. These relative chances appear to have declined substantially for those born in the $1942-46$ period where the odds were somewhat under three to one. However, in all likelihood this trend is exaggerated. Respondents born in 1945 or 1946 , answering a 1966 survey, are only in rare instances going to be able to claim a university degree. Furthermore, in all probability more sons from privileged backgrounds were still pursuing university degrees in 1966 relative to sons from less privileged backgrounds. Therefore the apparently large narrowing of the gap in the final cohort is probably, at least partially, spurious.

We also know that educational inequalities occur at each level of schooling. Therefore, as Pike (1980: 134) notes, "much of the social selection for postsecondary education actually occurs through processes of selection which occur long before, in elementary and secondary schools" (see also Porter, 1970: 329). That is, calculating higher educational attendance rates as a proportion of all persons born to a particular cohort (as in Table 1) captures the cumulative impact of background attributes over all levels of schooling. While examination of these cumulative effects are appropriate for some purposes (see below), specific postsecondary effects can also be calculated. To do so requires comparing the number of people going on to some form of postsecondary education with the number of individuals eligible to do so. As before, these more specific transition rates may be cross-classified by the independent variables of interest.

\section{Data and Methods}

The three hypotheses outlined above were tested using data from the 1973 Canadian Mobility Study conducted by Boyd et al. (1981). The final sample consisted of 44,867 male and female respondents, over the age of 17 , who were not full-time students (the student constraint is returned to below). The analysis was restricted to a subset of this larger sample by focusing on birth cohorts 
composed of respondents born in Canada between 1910 and $1949 .^{6}$

The following procedures were used to measure the variables of interest. Access to higher education was measured by answers which respondents gave to questions concerning their attendance at postsecondary educational institutions. Birth cohorts, used to assess changes over time, were based on individual reports of year of birth. Ethnicity was based on language group - either English or French. ${ }^{7}$ Socioeconomic background was based on father's occupation (at the time the respondent was 16). Four occupational categories were used - farmers, blue collar, white collar, and professional/managerial (prof/man) workers.

A series of caveats accompany interpretation of this data. First, the use of birth cohorts with cross-sectional data is subject to problems of differential cohort mortality, as well as the fallibility of the memories of older respondents (see the discussion in Halsey, Heath and Ridge, 1980). Second, the focus is upon access to postsecondary education, and the quality of education is not examined. Third, although a distinction between community college and university education is made, no finer distinctions are assessed. Fourth, regional patterns are not examined. Fifth, the analysis strategy relies on bivariate comparisons and no higher order interactions are considered. ${ }^{8}$ Sixth, undoubtedly some respondents will have improved their educational credentials after the survey was conducted, via continuing or adult education, and these improvements remain unexamined. ${ }^{9}$ Despite these limitations, an initial examination of national changes over the course of this century provides some significant detail concerning the extent of democratization of higher education.

\section{Data Analysis}

Table 2 provides a cross-classification of birth cohort and socioeconomic background for respondents who reported some postsecondary educational experience. As revealed by the column totals, the overall percentage of respondents with such experience has increased from 23.2 percent for the earliest birth

Table 2: Post-Secondary Attendance $(\%)$ by father's Occupation and Birth Cohort

\begin{tabular}{|c|c|c|c|c|c|c|c|c|c|}
\hline \multirow[b]{2}{*}{$\begin{array}{l}\text { Father:s } \\
\text { Occupation }\end{array}$} & \multicolumn{8}{|c|}{ Birth cohor: } & \multirow[b]{2}{*}{$\begin{array}{l}\text { Row } \\
\text { Totals }\end{array}$} \\
\hline & $1910-14$ & $1915-49$ & $1920-24$ & $1925-29$ & $1930-34$ & $1935-39$ & $1940-44$ & $1944-49$ & \\
\hline Prof/Man & $\begin{array}{r}45.2 \\
3.0 .1 \\
1.10\end{array}$ & $\begin{array}{r}45.7 \\
2.6: 9 \\
0.97\end{array}$ & $\begin{array}{r}47.2 \\
2.7: 1 \\
0.99\end{array}$ & $\begin{array}{r}46.6 \\
2.3: 1 \\
0.83\end{array}$ & $\begin{array}{r}52.7 \\
2.2: 1 \\
0.78\end{array}$ & $\begin{array}{r}60.0 \\
2.1: 1 \\
0.72\end{array}$ & $\begin{array}{r}62.5 \\
1.7 ; 1 \\
0.51\end{array}$ & $\begin{array}{r}65.2 \\
1.6: 1 \\
0.47\end{array}$ & $\begin{array}{c}55.9 \\
(4072)\end{array}$ \\
\hline $\begin{array}{l}\text { White } \\
\text { collar }\end{array}$ & $\begin{array}{r}37.9 \\
2.5: 1 \\
0.93\end{array}$ & $\begin{array}{r}34.7 \\
2.0: 1 \\
0.70\end{array}$ & $\begin{array}{r}42.2 \\
2.4: 9 \\
0.88\end{array}$ & $\begin{array}{r}42.2 \\
2.1: 1 \\
0.73\end{array}$ & $\begin{array}{r}43.1 \\
1.8: 1 \\
0.58\end{array}$ & $\begin{array}{r}47.7 \\
1.6: 1 \\
0.49\end{array}$ & $\begin{array}{r}53.0 \\
1.4 .1 \\
0.35\end{array}$ & $\begin{array}{r}52.6 \\
3: 1 \\
0.26\end{array}$ & $\begin{array}{c}46.4 \\
(2290)\end{array}$ \\
\hline $\begin{array}{l}\text { Blue } \\
\text { Collar }\end{array}$ & $\begin{array}{r}19.8 \\
13: 1 \\
0.28\end{array}$ & $\begin{array}{r}20.0 \\
1.2: 1 \\
0.15\end{array}$ & $\begin{array}{r}22.0 \\
1.3: \\
0.23\end{array}$ & $\begin{array}{r}21.4 \\
1: 1 \\
0.05\end{array}$ & $\begin{array}{r}24.7 \\
1: 1 \\
0.02\end{array}$ & $\begin{array}{r}30.1 \\
1: 1 \\
0.03\end{array}$ & $\begin{array}{r}38.0 \\
1: 1 \\
0.01\end{array}$ & $\begin{array}{r}37.5 \\
.9 .1 \\
-0.08\end{array}$ & $\begin{array}{c}28.8 \\
(9388)\end{array}$ \\
\hline Farm & $\begin{array}{c}15.0 \\
1: 1 \\
0\end{array}$ & $\begin{array}{c}17.3 \\
1: 1 \\
0\end{array}$ & $\begin{array}{c}17.5 \\
1: 1 \\
0\end{array}$ & $\begin{array}{c}20.4 \\
1: 1 \\
0\end{array}$ & $\begin{array}{c}24.1 \\
1: 1 \\
0\end{array}$ & $\begin{array}{c}29.1 \\
1: 1 \\
0\end{array}$ & $\begin{array}{c}37.5 \\
1: 1 \\
0\end{array}$ & $\begin{array}{c}40.7 \\
1: 1 \\
0\end{array}$ & $\begin{array}{c}24.3 \\
(5883)\end{array}$ \\
\hline $\begin{array}{l}\text { Column } \% \\
\text { Totals }\end{array}$ & $\begin{array}{l}23.2 \\
1687\end{array}$ & $\begin{array}{l}24.4 \\
2262\end{array}$ & $\begin{array}{l}25.2 \\
2532\end{array}$ & $\begin{array}{l}27.2 \\
2545\end{array}$ & $\begin{array}{l}31.4 \\
2695\end{array}$ & $\begin{array}{l}37.4 \\
2562\end{array}$ & $\begin{array}{l}44.8 \\
3208\end{array}$ & $\begin{array}{l}46.6 \\
4145\end{array}$ & 21634 \\
\hline
\end{tabular}

The total $\mathrm{N}$ for each column (e.g. 1.687 in column 1) represents the tatal number of native-born Canadians in the sample for each birth cohort. 
cohort (1910-14), to 46.6 percent for the last cohort (1945-49). This means that slightly more than one-fifth of those people born just prior to WW I, obtained some postsecondary education, whereas for those born just after WW II, almost half obtained such experience. Furthermore, when assessing increases across cohorts within each specific socioeconomic category (e.g., farm, blue collar, etc.), the percentages have also risen.

Although the proportion of respondents in each cohort who report postsecondary attendance has risen for each socioeconomic category, the three hypotheses focus upon whether such increases are constant across groups, or whether the rates are converging in either a steady or accelerating pattern. The disparity ratios suggest that the influence of socioeconomic background on postsecondary attendance has steadily decreased over time; the log-distance measures reveal a similar pattern. For the earliest cohort, respondents from prof/man backgrounds were three times more likely than their rural peers to acquire some postsecondary training: the disparity ratio is $3.0: 1$, the percentage difference is 45.2 versus 15.0. In the 1945-49 cohort the relative odds had decreased to 1.6: 1. Other comparisons (e.g., prof/man versus blue collar) also reveal a steady decline in the importance of socioeconomic background. Of all the possible comparisons, it is only with respect to differences between people from white collar versus $\mathrm{prof} / \mathrm{man}$ backgrounds that no reduction in disparity has occurred.

In Table 3 the analysis narrows to an assessment of socioeconomic trends for those who report a university degree. The patterns here are strikingly different from the previous table, and there is certainly no steady decline in disparity ratios over time. Neither does it appear that the rates are perfectly constant across time, although how substantially the disparities have narrowed in the last two or three cohorts is difficult to pinpoint. First, when comparing those from white collar backgrounds with those from either blue collar or farm backgrounds, a reduction in disparity ratios exists (from the $3: 1$ range to the $1.5: 1$ range). ${ }^{10}$ Second, comparing respondents from prof/man backgrounds to those from either blue collar or farm origins reveals a curvilinear pattern, in that initially the dis-

Table 3: Attaimment of a University vegree $(\%)$ by Father's Dccupation and Birth Cohort

Birth cohort

\begin{tabular}{|c|c|c|c|c|c|c|c|c|c|}
\hline $\begin{array}{l}\text { Father's } \\
\text { Dccupat Ion }\end{array}$ & $1910-14$ & $1915-19$ & $1920-24$ & $1925-29$ & $1930-34$ & $1935-39$ & $1940-44$ & $1944-49$ & $\begin{array}{l}\text { Row } \\
\text { Totals }\end{array}$ \\
\hline Prof/Man & $\begin{array}{r}7.5 \\
3.3: 1 \\
1.18\end{array}$ & $\begin{array}{r}10.2 \\
4.1: 1 \\
1.41\end{array}$ & $\begin{array}{r}11.6 \\
7.7: 1 \\
2.05\end{array}$ & $\begin{array}{r}12.3 \\
4.1: 1 \\
1.41\end{array}$ & $\begin{array}{r}17.3 \\
4.8: 1 \\
1.57\end{array}$ & $\begin{array}{r}21.2 \\
3.8: 1 \\
1.33\end{array}$ & $\begin{array}{r}22.3 \\
3.4: 1 \\
1.23\end{array}$ & $\begin{array}{r}19.6 \\
2.5: 1 \\
0.93\end{array}$ & $\begin{array}{c}16.8 \\
(4073)\end{array}$ \\
\hline $\begin{array}{l}\text { white } \\
\text { Collar }\end{array}$ & $\begin{array}{r}9.3 \\
4.0: 1 \\
1.40\end{array}$ & $\begin{array}{r}4.2 \\
1.7: 1 \\
0.52\end{array}$ & $\begin{array}{r}6.3 \\
4.2: 1 \\
1.44\end{array}$ & $\begin{array}{r}7.6 \\
2.5: 1 \\
0.93\end{array}$ & $\begin{array}{r}9.9 \\
2.8: 1 \\
1.01\end{array}$ & $\begin{array}{r}8.1 \\
4.4: 1 \\
0.37\end{array}$ & $\begin{array}{r}10.6 \\
1.6: 1 \\
0.49\end{array}$ & $\begin{array}{r}11.6 \\
1.5: 1 \\
0.41\end{array}$ & $\begin{array}{c}9.1 \\
(2290)\end{array}$ \\
\hline $\begin{array}{l}\text { Blue } \\
\text { collar }\end{array}$ & $\begin{array}{r}2.0 \\
-9: 1 \\
-0.14\end{array}$ & $\begin{array}{r}2.7 \\
1.1 .1 \\
0.08\end{array}$ & $\begin{array}{r}3.0 \\
2.0 .1 \\
0.69\end{array}$ & $\begin{array}{r}2.4 \\
8: 1 \\
-0.22\end{array}$ & $\begin{array}{r}3.3 \\
9: 1 \\
-0.09\end{array}$ & $\begin{array}{r}4.6 \\
8: 1 \\
-0.20\end{array}$ & $\begin{array}{r}5.9 \\
9: 1 \\
-0.10\end{array}$ & $\begin{array}{r}6.3 \\
-8: 1 \\
-0.20\end{array}$ & $\begin{array}{c}4.2 \\
(9388)\end{array}$ \\
\hline Farm & $\begin{array}{c}2.3 \\
1: 1 \\
0\end{array}$ & $\begin{array}{c}2.5 \\
: 1 \\
0\end{array}$ & $\begin{array}{c}1: 5 \\
1: 1 \\
0\end{array}$ & $\begin{array}{c}3.0 \\
1: 1 \\
0\end{array}$ & $\begin{array}{c}3.6 \\
1: 1 \\
0\end{array}$ & $\begin{array}{c}5.6 \\
1: 1 \\
0\end{array}$ & $\begin{array}{c}6.5 \\
1: 1 \\
0\end{array}$ & $\begin{array}{c}7.7 \\
1: 1 \\
0\end{array}$ & $\begin{array}{c}3.9 \\
(5883)\end{array}$ \\
\hline $\begin{array}{l}\text { Column } \% \\
\text { Totals }\end{array}$ & $\begin{array}{r}3.6 \\
1686\end{array}$ & $\begin{array}{r}3.9 \\
2262\end{array}$ & $\begin{array}{r}4.1 \\
2532\end{array}$ & $\begin{array}{r}4.8 \\
2545\end{array}$ & $\begin{array}{r}6.6 \\
2695\end{array}$ & $\begin{array}{r}8.3 \\
2561\end{array}$ & $\begin{array}{l}10.0 \\
3207\end{array}$ & $\begin{array}{l}10.4 \\
4: 46\end{array}$ & 21633 \\
\hline
\end{tabular}


parities diverge, only to converge in the later periods. Certainly a comparison of those born in the twenties and those born in the forties suggests a modest convergence. Finally, comparing people from prof/man and white collar origins presents a mixed pattern showing little discernible difference over time (as in Table 2).

While the data suggest that some reduction has occurred, this interpretation may be premature if we consider that by 1973 some potential respondents, born in the last cohort, probably had not completed their education and therefore were ineligible for the sample. If this possibility is similar for each socioeconomic category, then no problems arise. However, it is probable that more respondents from prof/man origins, who were still at school, were excluded, and therefore the 19.6 percent in the upper righthand cell is likely an underestimate. Thus, the reduction noted in Table 3 is probably even more modest than appears. Nevertheless, and especially when Lagace's (1968) results are also considered (Table 1), a minor shift toward equality of attainment has occurred.

A comparison of Tables 2 and 3 clearly reveals that the democratization of postsecondary education has not come about because of processes occurring at the university level. In terms of university degree completion only a minor reduction in socioeconomic disparities has occurred. Not only are socioeconomic disparities larger at the university level (compare log distances between Tables 2 and 3 ), but these inequalities have also receded only minimally when compared with the general pattern at the postsecondary level.

Striking differences between postsecondary exposure and university graduation are also apparent when focusing upon male-female differences. First, as shown in Table 4, females have generally had more exposure to postsecondary schooling, although the initial gap has closed in more recent cohorts. The higher enrolments of women in the early period stems largely from their participation in postsecondary teaching and nursing programmes, participation that was necessary in order to secure employment in a highly segmented labour force.

\begin{tabular}{|c|c|c|c|c|c|c|c|c|c|c|}
\hline \multirow[b]{2}{*}{$\frac{\text { Level }}{\text { Eawcation }}$} & \multirow[b]{2}{*}{$\underline{\text { Sex }}$} & \multicolumn{6}{|c|}{ Birth Gonort } & \multirow[b]{2}{*}{$1940-44$} & \multirow[b]{2}{*}{$1944-49$} & \multirow[b]{2}{*}{$\begin{array}{l}\text { Row } \\
\text { Totals }\end{array}$} \\
\hline & & $1910-14$ & $1915-19$ & $1920-24$ & $1925-29$ & $1930-34$ & $1935-39$ & & & \\
\hline \multirow{2}{*}{$\begin{array}{l}\text { Some Post- } \\
\text { Secondary } \\
\text { Exper ience }\end{array}$} & Males & $\begin{array}{r}19.7 \\
.8 .1 \\
-\quad 23\end{array}$ & $\begin{array}{r}19.8 \\
-8: 1 \\
-.21\end{array}$ & $\begin{array}{r}23.0 \\
8: 1 \\
-\quad 18\end{array}$ & $\begin{array}{r}24.7 \\
-9: 1 \\
-.10\end{array}$ & $\begin{array}{r}29.7 \\
+: 1 \\
-\quad 03\end{array}$ & $\begin{array}{r}35.4 \\
1: 1 \\
.01\end{array}$ & $\begin{array}{r}42.2 \\
1: 1 \\
-.01\end{array}$ & $\begin{array}{r}44.1 \\
1: 1 \\
-\quad 01 \\
\end{array}$ & $\begin{array}{l}31.5 \\
(12470)\end{array}$ \\
\hline & females & $\begin{array}{c}24.9 \\
1: 1 \\
0\end{array}$ & $\begin{array}{c}24.5 \\
1: 1 \\
0\end{array}$ & $\begin{array}{c}27.3 \\
1: 1 \\
0\end{array}$ & $\begin{array}{c}27.3 \\
1: 1 \\
0\end{array}$ & $\begin{array}{c}30.6 \\
1: 1 \\
0\end{array}$ & $\begin{array}{c}35.3 \\
1: 1 \\
0\end{array}$ & $\begin{array}{c}42.6 \\
1: 1 \\
0\end{array}$ & $\begin{array}{c}44: 9 \\
1: 1 \\
0\end{array}$ & $\begin{array}{c}33.8 \\
(13013)\end{array}$ \\
\hline \multirow{4}{*}{$\begin{array}{l}\text { Attain } \\
\text { Untversity } \\
\text { Degree }\end{array}$} & $\begin{array}{ll}\text { Column } & X \\
\text { rotals } & N\end{array}$ & $\begin{array}{l}22.2 \\
2066\end{array}$ & $\begin{array}{l}22.6 \\
2747\end{array}$ & $\begin{array}{l}25.2 \\
3046\end{array}$ & $\begin{array}{l}26.0 \\
3014\end{array}$ & $\begin{array}{l}30.1 \\
3176\end{array}$ & $\begin{array}{l}35.4 \\
2988\end{array}$ & $\begin{array}{l}42.4 \\
3702\end{array}$ & $\begin{array}{l}44.5 \\
4744\end{array}$ & 25484 \\
\hline & Males & $\begin{array}{r}3.4 \\
1.3: 1 \\
0.27\end{array}$ & $\begin{array}{r}5.2 \\
2.6: 1 \\
0.96\end{array}$ & $\begin{array}{r}5.9 \\
2.7: 1 \\
0.99\end{array}$ & $\begin{array}{r}7.2 \\
4: 1 \\
1.39\end{array}$ & $\begin{array}{r}8.9 \\
2.8: 1 \\
1.02\end{array}$ & $\begin{array}{r}12.0 \\
3.3: 1 \\
1.20\end{array}$ & $\begin{array}{r}12.9 \\
2.6: 1 \\
0.95\end{array}$ & $\begin{array}{r}12.6 \\
1.9 .1 \\
0.62\end{array}$ & $\begin{array}{c}9.1 \\
(12469)\end{array}$ \\
\hline & femares & $\begin{array}{c}2.6 \\
1: 1 \\
0\end{array}$ & $\begin{array}{l}2.0 \\
1: 1 \\
0\end{array}$ & $\begin{array}{c}2.2 \\
1: 1 \\
0\end{array}$ & $\begin{array}{c}1.8 \\
1: 1 \\
0\end{array}$ & $\begin{array}{c}3.2 \\
1: 1 \\
0\end{array}$ & $\begin{array}{c}3.6 \\
1: 1 \\
0\end{array}$ & $\begin{array}{c}5.0 \\
1: 1 \\
0\end{array}$ & $\begin{array}{c}6.8 \\
1: 1 \\
0\end{array}$ & $\begin{array}{l}3.7 \\
(13014)\end{array}$ \\
\hline & $\begin{array}{ll}\text { Column } & x \\
\text { Totals } & N\end{array}$ & $\begin{array}{r}3.0 \\
2065\end{array}$ & $\begin{array}{r}3.6 \\
2747\end{array}$ & $\begin{array}{r}4.0 \\
3046\end{array}$ & $\begin{array}{r}4.4 \\
3014\end{array}$ & $\begin{array}{r}6.0 \\
3177\end{array}$ & $\begin{array}{r}7.7 \\
2988\end{array}$ & $\begin{array}{r}8.9 \\
3702\end{array}$ & $\begin{array}{r}9.6 \\
4745\end{array}$ & 25483 \\
\hline
\end{tabular}


The opposite pattern holds at the university level where men have always had the greater likelihood of graduating. This trend appears curvilinear, with the disparity between women and men growing until the 1930-34 cohort and then decreasing to about $2: 1$ by the last cohort. ${ }^{11}$

Table 5 presents similar information although here the comparison is between French and English Canadians. At the general postsecondary level, the steady decline hypothesis fits the data reasonably closely. Over time the greater odds of the English receiving some postsecondary exposure have declined, although even in the last cohort the English have slightly better odds. Examining the pattern for respondents reporting university degrees reveals a modest, although by no means substantial, decline in the French - English disparity. The odds over the 1910-25 period favour the English by about 2:1, decreasing in the later years to about $1.5: 1$.

To this point the analysis has focused upon the percentage of all people in a given cohort who have attended or attained some form of postsecondary schooling. The disparities found could, however, have occurred for a variety of reasons, including failure to complete high school or deciding not to continue school even though technically eligible. The final table therefore examines respondents who report obtaining a university degree, as a percentage of those eligible to proceed to university. For this table the percentage base shifts from all people in a cohort to those in a cohort who are eligible to attend university. ${ }^{12}$

The most telling piece of information in Table 6 is the minimal increase over time in the percentage of eligible Canadians who go on to complete a university degree. Whereas in cohorts from the 1910's and 1920's about 30 percent of eligible Canadians reported receiving university degrees, this percentage has risen to only 36 or 37 percent for those born in the 1940's. The much touted expansion of higher education has had, at best, a modest impact on the percentage of eligible Canadians receiving university degrees. ${ }^{13}$

With respect to differences by socioeconomic status, the greatest advantage

Taple 5: Post-Secondary attendance $(\%)$ and University Degroe Attainment $(\%)$ by Language Group and Birth Cohort

Birth Cohort

\begin{tabular}{|c|c|c|c|c|c|c|c|c|c|c|}
\hline \multirow[b]{2}{*}{$\frac{\text { Level }}{\text { Educat of }} \frac{y_{10}}{}$} & \multicolumn{10}{|c|}{ 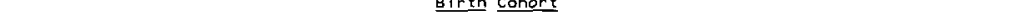 } \\
\hline & $\begin{array}{l}\text { Language } \\
\text { Group }\end{array}$ & $1910-14$ & $1915-19$ & $1920-24$ & $1925-29$ & $1930-34$ & $1935-39$ & $1940-44$ & $1944-49$ & $\begin{array}{l}\text { Row } \\
\text { Totals }\end{array}$ \\
\hline \multirow{2}{*}{$\begin{array}{l}\text { Some Past } \\
\text { Secondary } \\
\text { Exper ence }\end{array}$} & English & $\begin{array}{r}28.1 \\
3: 1 \\
1.12\end{array}$ & $\begin{array}{r}26.8 \\
2: 1 \\
.70\end{array}$ & $\begin{array}{r}31.3 \\
2.3: 1 \\
.82\end{array}$ & $\begin{array}{r}31.3 \\
2: 1 \\
.62\end{array}$ & $\begin{array}{r}34.9 \\
1.7: 1 \\
.53\end{array}$ & $\begin{array}{r}40.5 \\
1.6: 1 \\
.47\end{array}$ & $\begin{array}{r}46.6 \\
1.3: 1 \\
.30\end{array}$ & $\begin{array}{r}47.9 \\
1.3: 1 \\
.24\end{array}$ & $\begin{array}{c}37.5 \\
(16982)\end{array}$ \\
\hline & Frenen & $\begin{array}{c}9.2 \\
1: 1 \\
0\end{array}$ & $\begin{array}{c}13.3 \\
1: 1 \\
0\end{array}$ & $\begin{array}{c}13.8 \\
1: 1 \\
0\end{array}$ & $\begin{array}{c}15.8 \\
1: 1 \\
0\end{array}$ & $\begin{array}{c}20.4 \\
1: 1 \\
0\end{array}$ & $\begin{array}{c}25.4 \\
1: 1 \\
0\end{array}$ & $\begin{array}{c}34.6 \\
1: 1 \\
0\end{array}$ & $\begin{array}{c}37.6 \\
1: 1 \\
0\end{array}$ & $\begin{array}{c}23.6 \\
(13013)\end{array}$ \\
\hline \multirow{4}{*}{$\begin{array}{l}\text { Attain } \\
\text { University } \\
\text { Oegree }\end{array}$} & $\begin{array}{l}\text { Column } \\
\text { Totals }\end{array}$ & $\begin{array}{l}22.7 \\
1990\end{array}$ & $\begin{array}{l}23.2 \\
2655\end{array}$ & $\begin{array}{l}25.7 \\
2950\end{array}$ & $\begin{array}{l}26.0 \\
2943\end{array}$ & $\begin{array}{l}30.3 \\
3094\end{array}$ & $\begin{array}{l}35,7 \\
2941\end{array}$ & $\begin{array}{l}42.8 \\
3640\end{array}$ & $\begin{array}{l}44.5 \\
4670\end{array}$ & 24883 \\
\hline & English & $\begin{array}{r}3.7 \\
2.5: 1 \\
0.90\end{array}$ & $\begin{array}{r}3.9 \\
1.3: 1 \\
0.30\end{array}$ & $\begin{array}{r}5.1 \\
2.4: 1 \\
0.89\end{array}$ & $\begin{array}{r}5.0 \\
1.5: 1 \\
0.42\end{array}$ & $\begin{array}{r}7.1 \\
1.7: 1 \\
0.53\end{array}$ & $\begin{array}{r}8.4 \\
1.3 \vdots 1 \\
0.29\end{array}$ & $\begin{array}{r}10.3 \\
1.6: 1 \\
0.48\end{array}$ & $\begin{array}{r}10.9 \\
1.6: 1 \\
0.44\end{array}$ & $\begin{array}{c}7.4 \\
(16982)\end{array}$ \\
\hline & french & $\begin{array}{c}1.5 \\
1: 1 \\
0\end{array}$ & $\begin{array}{c}2.9 \\
1: 1 \\
0\end{array}$ & $\begin{array}{c}2.1 \\
1: 1 \\
0\end{array}$ & $\begin{array}{c}3.3 \\
1: 1 \\
0\end{array}$ & $\begin{array}{c}4.2 \\
1: 1 \\
0\end{array}$ & $\begin{array}{c}6.3 \\
1: 1 \\
0\end{array}$ & $\begin{array}{c}6.4 \\
1: 1 \\
0\end{array}$ & $\begin{array}{c}7.0 \\
1: 1 \\
0\end{array}$ & $\begin{array}{c}4.6 \\
(7901)\end{array}$ \\
\hline & $\begin{array}{ll}\text { Column } & X \\
\text { Totals } & \end{array}$ & $\begin{array}{r}3.1 \\
1990\end{array}$ & $\begin{array}{r}3.7 \\
2655\end{array}$ & $\begin{array}{r}4.1 \\
2950\end{array}$ & $\begin{array}{r}4.4 \\
2943\end{array}$ & $\begin{array}{r}6.2 \\
3094\end{array}$ & $\begin{array}{r}7.8 \\
2941\end{array}$ & $\begin{array}{r}9.0 \\
3640\end{array}$ & $\begin{array}{r}9.7 \\
4670\end{array}$ & 24883 \\
\hline
\end{tabular}


has accrued to those from white collar backgrounds. Individuals from white collar origins have done relatively better than people from either blue collar or farm backgrounds, and they have gained ground on those from prof/man families. A comparison of prof/man with both blue collar and farm respondents suggests virtually no change over time. Moreover, the greater ability of farmers' sons and daughters, relative to individuals from blue collar homes, to complete degrees once eligible for university is both unexpected and interesting.

The findings in Tables 3 and 6 suggest that massive increases in government spending on higher education ${ }^{14}$ and the institution of student aid programmes ${ }^{15}$ did little to increase equality of opportunity at the university level. While the figures in Table 2 reveal reduced socioeconomic disparities for postsecondary education, this reduction must have come from one main source. The rapid emergence of community colleges or technical institutes in all provinces created opportunities for individuals from farm and blue collar backgrounds. General postsecondary reductions in socioeconomic disparities are thus largely results of non-university higher educational expansion (see Pike, 1981:33).

\section{Discussion and Conclusion}

The central purpose of this paper has been to examine, using a large national sample, the long-term historical trends in access to higher education. The main findings can be summarized as follows. First, an overall reduction in educational disparities has occurred at the postsecondary level with respect to gender, language group, and socioeconomic background. This is in general accord with the steadily declining gap hypothesis. Second, although disparities have been reduced, they have been eliminated only in terms of differences between men and women in general postsecondary participation rates. Third, with respect to university degree attainment, reductions in disparity have been minimal, with the greatest convergence coming in terms of French - English differences.

These findings raise four important issues: has a dual higher educational system evolved in this country; does the data reveal a trend toward greater accessibility

\begin{tabular}{|c|c|c|c|c|c|c|c|c|c|}
\hline \multirow[b]{2}{*}{$\begin{array}{l}\text { Father's } \\
\text { occupation }\end{array}$} & Tab1e & \multicolumn{7}{|c|}{$\begin{array}{l}\text { 5: Attainment of a University Degree }(\%) \text { for Eligible University } \\
\text { Students by Father's Dccupatian and Birth Cohort } \\
\text { Biren cohort }\end{array}$} & \multirow[b]{2}{*}{$\begin{array}{l}\text { Row } \\
\text { Totals }\end{array}$} \\
\hline & $1910-14$ & $1915-19$ & $1920-24$ & $1925-29$ & $1930-34$ & $1935-39$ & $1940-44$ & $1944-49$ & \\
\hline Prof/Man & $\begin{array}{r}41.0 \\
1.1 .1 \\
0.07\end{array}$ & $\begin{array}{r}41.3 \\
1.7: 1 \\
0.52\end{array}$ & $\begin{array}{r}43.6 \\
1.6: 1 \\
0.47\end{array}$ & $\begin{array}{r}42.0 \\
1.4: 1 \\
0.43\end{array}$ & $\begin{array}{r}48.6 \\
1.8: 1 \\
0.57\end{array}$ & $\begin{array}{r}50.5 \\
1.4: 1 \\
0.34\end{array}$ & $\begin{array}{r}50.0 \\
1.7 .1 \\
0.53\end{array}$ & $\begin{array}{r}50.4 \\
+5.1 \\
0.42\end{array}$ & $\begin{array}{c}47.7 \\
(2412)\end{array}$ \\
\hline $\begin{array}{l}\text { White } \\
\text { Collar }\end{array}$ & $\begin{array}{r}48.3 \\
1.3: 1 \\
0.23\end{array}$ & $\begin{array}{l}25.0 \\
1: 1 \\
0.02\end{array}$ & $\begin{array}{r}26.2 \\
1: 1 \\
-0.04 \\
\end{array}$ & $\begin{array}{r}32.4 \\
1: 1 \\
0.17\end{array}$ & $\begin{array}{r}34.4 \\
1.2: 1 \\
0.22 \\
\end{array}$ & $\begin{array}{r}34.7 \\
1.1 \\
-0.03\end{array}$ & $\begin{array}{r}37.6 \\
1.3 .1 \\
0.25\end{array}$ & $\begin{array}{r}41.3 \\
1.221 \\
0.22 \\
\end{array}$ & $\begin{array}{c}36.1 \\
(1171)\end{array}$ \\
\hline $\begin{array}{l}\text { Blue } \\
\text { Collar }\end{array}$ & $\begin{array}{r}25.5 \\
0.7: 1 \\
-0.41\end{array}$ & $\begin{array}{r}22.4 \\
0.9: 1 \\
-0.09\end{array}$ & $\begin{array}{r}27.5 \\
1: 1 \\
0.01\end{array}$ & $\begin{array}{r}22.5 \\
0.7: 1 \\
-0.19\end{array}$ & $\begin{array}{r}24.2 \\
0.9: 1 \\
-0.13\end{array}$ & $\begin{array}{r}27.9 \\
0.8: 1 \\
-0.25\end{array}$ & $\begin{array}{l}29.5 \\
1.1 \\
0.01\end{array}$ & $\begin{array}{r}26.6 \\
0.8: 1 \\
-0.22\end{array}$ & $\begin{array}{c}26.5 \\
(9388)\end{array}$ \\
\hline Farm & $\begin{array}{c}38.4 \\
1: 1 \\
0\end{array}$ & $\begin{array}{c}24.6 \\
1: 1 \\
0\end{array}$ & $\begin{array}{c}27.2 \\
1: 1 \\
0\end{array}$ & $\begin{array}{c}30.9 \\
1: 1 \\
0\end{array}$ & $\begin{array}{c}27.6 \\
1: 1 \\
0\end{array}$ & $\begin{array}{c}35.8 \\
:-1 \\
0\end{array}$ & $\begin{array}{c}29.3 \\
1: 1 \\
0 \\
\end{array}$ & $\begin{array}{c}33.1 \\
1: 1 \\
0\end{array}$ & $\begin{array}{c}30.7 \\
(1579)\end{array}$ \\
\hline $\begin{array}{l}\text { Column } \\
\text { Totals }\end{array}$ & $\begin{array}{r}36.3 \\
424\end{array}$ & $\begin{array}{r}28.9 \\
633\end{array}$ & $\begin{array}{r}31.8 \\
732\end{array}$ & $\begin{array}{r}31.2 \\
764\end{array}$ & $\begin{array}{r}33.4 \\
943\end{array}$ & $\begin{array}{l}36.8 \\
1027\end{array}$ & $\begin{array}{l}36.5 \\
1580\end{array}$ & $\begin{array}{l}35.6 \\
2242\end{array}$ & 8246 \\
\hline
\end{tabular}

The total $N$ in this table $(8,246)$ represents the number of native-born Canadians in the sample who report completing high senool. 
as opposed to an historical anomaly soon to be reversed; what policy relevance stems from inequities in the distribution of opportunity; and finally what does this mean for the place of university education in the contemporary world?

The effects of higher educational expansion in Canada; as this relates to equality of opportunity, would seem to have operated to preserve the place of privilege at the university level. At least for Canadians born in the first half of this century, chances for obtaining a university degree have been consistently better for middle and upper class English-Canadian males. The democratization of postsecondary education, which clearly did occur, resulted mainly from the expansion of opportunities presented by the opening of numerous non-university colleges and institutes. This result is remarkably similar to the dual system of higher education described in both France and the United States (Patterson, 1976) and is clearly consistent with Porter's (1970: 329) view that community colleges were "a major postsecondary alternative for lower social and economic strata."

Whether the level of democratization reflected above will be maintained over the next few decades is also unclear. While most of the postsecondary disparities examined persist, they have been reduced, although the permanence of the reduction may well be undercut as higher education faces increasing financial pressure from governments. If Porter (1979: 195) is correct in arguing that the "full democratization of higher education requires innovation" and, if innovative programmes are curtailed in the wake of financial cutbacks, then retrenchment may reinforce the elitist leanings of postsecondary education.

Whatever the future directions of democratization, educational chances are currently unequal. The policy relevance of such inequality in the distribution of opportunity for higher education is difficult to overestimate. Increasingly occupational training, certification, and selection occurs through the educational system, particularly in postsecondary institutions. To the extent that this function is enhanced through time, while socially based disparities in opportunities for higher education (especially university) continue, then individual life chances must remain unequal. If higher education is contingent upon social attributes unrelated to academic ability - such as gender, ethnicity, and class - then in the end we waste precious resources by excluding gifted individuals. ${ }^{16}$

This is especially so if the post-industrial thesis of commentators such as Bell (1967) has any validity. If, as Bell (Ibid.:30) argues, "the university will become the central institution of the next one hundred years because of its role as the new source of innovation and knowledge", then Canadian higher education seems woefully ill equipped. We will be forced to continue our history of reliance on imported knowledge generators, innovators, and managers (Blishen, 1970; DeVoretz and Maki, 1983) or rely on a depleted stock of native-born talent. The consequences of this could be bleak indeed, as Canada tries to cope in a global market economy increasingly wed to creative knowledge and innovation.

An important adjunct to this general argument is the finding that the material rewards for university graduates, at least in terms of occupational attainment, 
have been declining in recent years (Anisef, 1982; Goyder, 1980; Harvey and Charner, 1975; Harvey and Kalwa, 1983). At a time when disparities in university undergraduate degree completion may be weakening, the value of such undergraduate degrees wane. While this is apparently the case, it is significant that university-educated individuals have lower unemployment rates than those lacking university credentials. In addition, while the fortunes of university graduates may have been diluted somewhat, they are still better off than their community college peers (see Goyder, 1980: 31-32). Thus, while some of the benefits of a university education may have tarnished slightly, the value of such an experience remains high, although still more difficult for some to enjoy.

In conclusion, changes in accessibility to higher education operate at two levels. While disparities have been reduced at the non-university level, at the university level democratization has only begun as a slow process. Furthermore, while reductions have occurred, at both levels social attributes remain correlated with both access and attainment.

\section{FOOTNOTES}

1. This difference could be due to a number of factors. For example, the studies differ on the measurement of social class, the composition of the samples (Canada vs. Ontario), as well as the slightly different time periods involved.

2. This trend is not limited to Canada but rather has almost universal applicability in industrialized countries (see Kotwal, 1975). Technically speaking it is the level of schooling which is measured, as opposed to the level of education.

3. In fact it is theoretically possible that if schooling levels were once allocated randomly but are now allocated ascriptively, then even with a narrowing of the distribution of schooling the process would be more unjust. As Mare (1980) points out, distribution properties and allocation properties are conceptually independent.

4. Unfortunately Lagace (1968) reported data based on only three, uneven birth cohorts. Furthermore, his own interpretation of the data is rather brief. It is perhaps for these reasons that his results have not been cited by most writers noted above (the sole exception is Pike, 1970).

5. Halsey, Heath and Ridge (1980:37) introduce disparity ratios in their analy ses of the U.K. school system. Owing to extremely low cell frequencies for some tables, they prefer to report "log distances" which are calculated by subtracting the natural logarithms of completion rates for specific categories. Log distances are reported here in all subsequent tables. These $\log$ distances also provide some assurance that disparity ratios are not decreasing as a simple function of ceiling effects. This latter problem arises because percentage rates have an upper limit of 100 (see Mare, 1980: 75; Guppy, Mikicich and Pendakur, 1984).

6. The sample is weighted to correct for: i) initial sampling stratification; and ii) possible bias due to differential response rates.

7. This measure used the language with which respondents were most comfortable at the time of the survey. All of the respondents included in the analysis were born in Canada.

8. This may be an important omission in certain cases. The increased participation of women in universities, who tend to come from higher socioeconomic backgrounds than 
undergraduate men (Harvey and Kalwa, 1983), may account for some of the apparent stability in socioeconomic disparities. Examining this issue is beyond the scope of the present paper.

9. This educational upgrading would present no problem in comparing rates across groups, if we could assume upgrading was pursued equally by all groups. This is highly unlikely (see e.g., Ahamad, Zussman and Bowen, 1976: 15-19).

10. It should be noted here that for the early periods the small sample size creates unstable estimates for specific cells. It is also here that social class differences in death rates may be most pronounced. However, the general pattern seems clear enough. The range of $3: 1$ for white collar respondents in the early period is a general average over the first four cohorts.

11. This curvilinear pattern is corroborated by Statistics Canada data on bachelor and first professional degrees awarded to men and women. In the period 1925-45 women received about 30 percent of the degrees awarded. This figure dipped to approximately 23 percent in the 1950's and then grew to some 37 percent in the 1960's (Statistics Canada, 1978).

12. This eligibility is measured by those respondents reporting either an academic high school certificate or some form of postsecondary experience. Eligibility is thus a measure of having completed the proper levels of schooling, but does not incorporate grades or examination success.

13. It is important to recognize a distinction between the percentage of eligible people obtaining a degree and the percentage of eligible people. While the former has increased only some eight or so percent, the latter has increased from about twenty-five percent to fifty-four percent (dividing the cohort totals in Table 6 by the corresponding totals in Table 3 provides an estimate of the latter, whereas the trend in the column percen. tages in Table 6 reveals the increase in the former). The ability of universities to enroll a rising proportion of a substantially increased pool of eligible Canadians is important, even if it meant only modest headway in achieving more democratic participation.

14. In 1950 the total financial expenditure on postsecondary education was $\$ 66.8$ million (or approximately 0.36 percent of the Canadian GNP), climbing to $\$ 2,220.8$ million (or about 2.6 percent of the GNP) in 1970. Most, although not all, of such expenditures are by governments. Of the 1970 figure, 80.6 percent was spent at the university level. From 1960 to 1970 community college funding increased 647 percent, while university funding grew by 556 percent. (Calculations are from Statistics Canada, 1978: 25 . 27 and 1983: 60)

15. While the major aid programme, the Canadian Student Loans Plan, was established in 1964 , the earliest concerted effort to provide public financial support to students came in the 1930's (see Pike, 1970; Porter, 1970). In 1957-58 "public financial aid amounted to $\$ 39.6$ per full-time undergraduate, increasing rapidly to $\$ 396.0$ per student by 1967-68" (Pike, 1970: 157). Although I can only speculate as to what might have happened had such funds not been available, it would seem that student aid money was used mainly by the middle classes as an educational subsidy.

16. Direct evidence for the assertion that individual talents are wasted is unavailable since unequal opportunities continue. There is evidence that increasing expenditures on U.S. education have increased economic output (Walters and Rubinson, 1983), but whether this is due to expanding opportunities is not clear. However, such inequality does run counter to a central tenet of liberal democracy, namely, the guarantee of "rights essential to the equal possibility of individual members using and developing their human capacities" (McPherson, 1978: 205). 


\section{REFERENCES}

Anisef, P. University graduates revisited: occupational mobility attainments and accessibility. Interchange, 1982, $13(2), 1-19$.

Anisef, P., Okihiro, N. \& James, C. The pursuit of equality: evaluating and monitoring accessibility to postsecondary education in Ontario. Toronto: Ministry of Education, 1982.

Ahamad, B., Zussman, D. \& Bowen, A. Some characteristics of postsecondary students in Canada. Ottawa: Thorn Press, 1976.

Bell, D. Notes on the post-industrial society. The Public Interest, 1967, 6, 24-35.

Blishen, B. Social class and opportunity in Canada. Canadian Review of Sociology and Anthropology, 1970, 7(2), 110-127.

Boyd, M., Goyder, J., Jones, F., McRoberts, H., Pineo, P. \& Porter, J. Status attainment in Canada, Canadian Review of Sociology and Anthropology, 1981, 18 (5), 657-673.

DeVoretz, D. \& Maki, D. The immigration of third world professionals to Canada: 1968 1973. World Development, 1983, 11 (1), 55-64.

Gaskell, J. Equal educational opportunity for women. In Wilson, J.D. (ed.) Canadian education in the 1980's, Calgary: Detselig, 1981, 173-193.

Goyder, J. Trends in the socioeconomic achievement of the university educated: a status attainment model interpretation. Canadian Journal of Higher Education, 1980 $X,(2), 21-38$.

Guppy, N., Mikicich, P. \& Pendakur, R. Changing patterns of educational inequality in Canada. Canadian Journal of Sociology, 1984, 9(3), 119-131.

Halsey, A., Heath, A. \& Ridge, J. Origins and destinations: family, class and education in modern Britain, Oxford: Clarendon Press, 1980.

Harp, J. Social inequalities and the transmission of knowledge: the case against the schools. In Harp, J. \& Hofley, J. (eds.) Structured Inequality in Canada, Toronto: PrenticeHall, 1980, 219-246.

Harvey, E. Accessibility to postsecondary education. University Affairs, 1977, October, 10-11.

Harvey, E. \& Charner, I. Social mobility and occupational attainments of university graduates. Canadian Review of Sociology and Anthropology, 1975, 12 (2), 134-149.

Harvey, E. \& Kalwa, R. Occupational status attainment of university graduates: individual attributes and labour market effects compared. Canadian Review of Sociology and Anthropology, 1983, 20(4), 435-453.

Hunter, A. Class tells: on social inequality in Canada Toronto: Butterworth, 1981.

Kotwal, M. Inequalities in the distribution of education between countries, sexes, generations, and individuals. In Education, Inequality and Life Chances Paris: OECD, 1975, 31-108.

Lagace, D. Educational attainment in Canada: some regional and social aspects, Special Labour Force Studies, No. 7, Dominion Bureau of Statistics, 1968.

Lennards, J. Education. In Hagedorn, R. (ed.) Sociology (2nd Ed.), Toronto: Holt, Rinehart and Winston, 1983, 433-467.

Mare, R. Social background and school continuation decisions. Journal of the American Statistical Association, 1980, 75, 295-305.

McPherson, C.B. Property: mainstream and critical positions, Toronto: University of Toronto Press, 1978.

Patterson, M. Government policy and equality in higher education: the junior collegization of the French university. Social Problems, 1976, 24 (2), 173-183. 
Pike, R. Who doesn't get to university - and Why, Ottawa: Runge Press, 1970.

Pike, R. Education, class, and power in Canada. Ossenberg, R. (ed.), Power and Change in Canada, Toronto: McClelland and Stewart, 1980, 106-145.

Pike, R. Contemporary directions and issues in education: a sociologist's view of the last twenty years. In Wilson, J.D. (ed.) Canadian education in the 1980's, Calgary: Delselig, 1981, 27-43.

Porter, J. Canadian universities: democratization and the need for a national system. Minerva, $1970,8(3), 325-356$.

Porter, J. Postindustrialism, postnationalism and postsecondary education. In Porter, J. The measure of Canadian society, Toronto: Gage, 1979, 185-206.

Richer, S. Equality to benefit from schooling: the issue of educational opportunity. In Forcese, D. \& Richer, S. (eds.) Social issues: sociological views of Canada, Toronto: Prentice-Hall, 1982, 336-374.

Simkus, A. \& Andorka, R. Inequalities in the educational attainment in Hungary, 19231973. American Sociological Review, 1982, 47(6), 740-751.

Statistics Canada. Historical compendium of educational statistics, Ottawa, 1978, Catalogue \# 81-568.

Statistics Canada. A statistical portrait of Canadian higher education, 1983 Edition, Ottawa, 1983 , Catalogue \#81-X-502E.

Sutherland, N. Introduction: toward a history of English-Canadian youngsters. In Katz, M. \& Mattingly, P. (eds.) Education and social change: themes from Ontario's Past, New York: New York Univ. Press, 1975, xi-xxxi.

Walters, P.B. \& Rubinson, R. Educational expansion and economic output in the United States, 1890-1969: a production function analysis. American Sociological Review, $1983,48(4), 480-493$. 